\title{
Environment and spray additive effects on picloram absorption and translocation in leafy spurge (Euphorbia esula) ${ }^{1}$
}

\author{
K. D. MOXNESS and R. G. LYM \\ The authors are former Grad. Res. Asst., and Assoc. Prof., Crop Weed Sci. Dep. N.D. State Univ., Fargo, ND 58105. \\ Present address of the senior author: Delamere, ND 58022.
}

\begin{abstract}
:
Relative humidity after application, spray additives, and solution $\mathrm{pH}$ affected both foliar absorption and translocation of ${ }^{14} \mathrm{C}$-picloram to leafy spurge roots. ${ }^{14} \mathrm{C}$-picloram absorption increased from 11 to $34 \%$ and translocation increased from 5 to $21 \%$ as time at posttreatment humidity increased from 0 to 48 hours. Absorption and translocation were not different when pre- or posttreatment temperatures were $30 / 18$ or $18 / 10^{\circ} \mathrm{C}$ (day/night). ${ }^{14} \mathrm{C}$-picloram absorption and translocation to the roots were 18 and $6 \%$, respectively, when applied alone, and increased to 46 and $12 \%$, respectively, when applied with ammonium sulfate at $2.5 \mathrm{~kg} / \mathrm{ha}$. Absorption and translocation were unaffected by ammonium nitrate. Foliar absorption and translocation of ${ }^{14} \mathrm{C}$-picloram in leafy spurge were unaffected by $\mathrm{pH}$ of unbuffered spray solution but increased at least $50 \%$ when applied in a solution buffered at $\mathrm{pH} 4.8$ with trisodium citrate. Foliar absorption in detached leafy spurge leaves increased from 26 to $51 \%$ of applied ${ }^{14} \mathrm{C}$ as the citrate buffer concentration increased from 0.01 to $0.1 \mathrm{mM}$, respectively.
\end{abstract}

\section{Nomenclature:}

Picloram, 4-amino-3,5,6-trichloro-2-pyridinecarboxylic acid; ammonium nitrate, $\mathrm{NH}_{4} \mathrm{NO}_{3}$; ammonium sulfate, $\left(\mathrm{NH}_{4}\right)_{2} \mathrm{SO}_{4}$; trisodium citrate, $\mathrm{Na}_{3} \mathrm{C}_{6} \mathrm{H}_{5} \mathrm{O}_{7} \cdot 2 \mathrm{H}_{2} \mathrm{O}$; leafy spurge, Euphorbia esula L. \# ${ }^{2}$ EPHES.

\footnotetext{
${ }^{1}$ Received for publication April 1, 1988, and in revised form November 20, 1988. This paper is taken in part from the M.S. Thesis of K. D. Moxness. Published with the approval of the Director, N.D. State Univ. Agric. Exp. Stn., as J. Art. No. 1673.

${ }^{2}$ Letters following this \# symbol are a WSSA-approved computer code from Composite List of Weeds, Weed Sci. 32 , Suppl. 2. Available from WSSA, 309 West Clark Street, Champaign, IL 61820.
} 


\section{Additional index words:}

Absorption and translocation, spray solution, $\mathrm{pH}$, fertilizer additive, EPHES.

\section{Introduction}

Several herbicides control leafy spurge shoots but translocation of the herbicides into the crown and root is insufficient to prevent regeneration (8). Picloram is the most effective herbicide available for leafy spurge control but generally is not economical for large infestations at rates required for long-term control $(6,10,13)$. Leafy spurge control with 2,4-D [(2,4-dichlorophenoxy) acetic acid], dicamba (3,6-dichloro-2-methoxybenzoic acid), or picloram is influenced by plant growth stage at the time of treatment and generally is most effective either when flowers and seeds are developing during early summer or when fall regrowth has developed (13).

Environmental conditions before, during, or after treatment often influence weed control with herbicides. Aspen poplar (Populus tremuloides Michx.) and balsam poplar (Populus balsamifera L.) leaves absorbed more picloram and 2,4-D at high than at low humidity and at $40^{\circ} \mathrm{C}$ compared to $10^{\circ} \mathrm{C}(22) .{ }^{14} \mathrm{C}$-picloram was more basipetally distributed in Canada thistle [Cirsium arvense (L.) Scop.] shoots when applied at high than at low humidity (21). Also, basipetal translocation of 2,4,5-T [(2,4,5-trichlorophenoxy) acetic acid] in mesquite [Prosopis juliflora (S.W.) DC.] seedlings was greater at $21^{\circ} \mathrm{C}$ than at $29^{\circ} \mathrm{C}(14)$.

The addition of ammonium salts has influenced picloram phytotoxicity in plants. Ammonium sulfate, ammonium nitrate, ammonium chloride $\left(\mathrm{NH}_{4} \mathrm{Cl}\right)$, ammonium dihydrogen phosphate $\left[\left(\mathrm{NH}_{4}\right)_{2} \mathrm{HPO}_{4}\right]$, and diammonium hydrogen phosphate $\left[\left(\mathrm{NH}_{4}\right)_{2} \mathrm{HPO}_{4}\right]$ increased the absorption of ${ }^{14} \mathrm{C}$-picloram by detached strawberry guava (Psidium cattleianum Sabine) leaves compared to ${ }^{14} \mathrm{C}$-picloram alone (35). However, absorption was similar when ${ }^{14} \mathrm{C}$-picloram was applied alone and with ammonium carbonate $\left[\left(\mathrm{NH}_{4}\right)_{2} \mathrm{CO}_{3}\right]$ or ammonium molybdate $\left[\left(\mathrm{NH}_{4}\right)_{5} \mathrm{Mo}_{7} \mathrm{O}_{24} \bullet 4 \mathrm{H}_{2} \mathrm{O}\right]$.

Picloram absorption increased as spray solution $\mathrm{pH}$ decreased in detached live oak (Quercus virginiana Mill.) leaves and potato (Solanum tuberosa L.) disks (4, 27). Greater root uptake of picloram at $\mathrm{pH} 3.5$ than at $\mathrm{pH} 4.5$ for oat (Avena sativa $\mathrm{L}$.) and soybean [Glycine max (L.) Merr.] has been reported (12). Adjustment of picloram solution $\mathrm{pH}$ with $\mathrm{HCI}$ or $\mathrm{NaOH}$, however, did not influence picloram absorption by detached strawberry guava leaves $(34,35)$.

The objective of this research was to determine the influence of environment, ammonium salts, and herbicide solution $\mathrm{pH}$ on the absorption and translocation of ${ }^{14} \mathrm{C}$-picloram in leafy spurge. The overall goal was to increase leafy spurge control by increasing the amount of picloram translocated to the root system. 


\section{Materials and methods}

\section{Plant preparation}

Leafy spurge roots were obtained from a natural infestation (accession 1984 ND 001) near Fargo, ND, divided into 2- to 3-cm sections, and planted in greenhouse flats containing Fairdale silty loam and peat $(1: 1, \mathrm{v} / \mathrm{v})$. Plants were propagated in the greenhouse at 21 to $27^{\circ} \mathrm{C}$ with supplemental fluorescent light $\left(100 \mu \mathrm{E} \cdot \mathrm{m}^{-2} \cdot \mathrm{s}^{-1}\right)$ when necessary for a 16hour light and 8-hour dark photoperiod. Plants were transplanted to 0.5- and then 1-L pots when approximately 10 and $20 \mathrm{~cm}$ tall, respectively. Leafy spurge stem and leaves were removed at the soil surface after the second transplanting, and one stem/pot was allowed to re-grow to a mid- to late-vegetative growth stage $(20$ to $30 \mathrm{~cm}$ tall) before treatment. Foliar absorption and translocation of ${ }^{14} \mathrm{C}$-picloram were greatest at this growth stage compared to the early vegetative or flowering stages in preliminary experiments (data not shown). Plants of uniform size were selected for each experiment.

\section{Humidity and temperature}

Leafy spurge plants were transferred from the greenhouse to growth chambers 24 hours before treatment. Growth chamber conditions were either high (90 to 95\%) or low (20 to $30 \%$ ) relative humidity at $30 / 18^{\circ} \mathrm{C}$ day/night temperatures with a 16-hour light $\left(700 \mu \mathrm{E} \cdot \mathrm{m}^{-2} \cdot \mathrm{s}^{-1}\right)$ and 8 -hour dark photoperiod.

One leaf midway on the stem of each plant was enclosed with a protective envelope made from two small strips of paper bound with tape. Picloram potassium salt was applied at $0.28 \mathrm{~kg}$ ae/ha with a moving-nozzle pot sprayer delivering $140 \mathrm{~L} / \mathrm{ha}$ at $280 \mathrm{kPa}$. The protective envelope was removed from the leaf and $5 \mu 1$ of $0.15 \%(\mathrm{v} / \mathrm{v})$ nonionic surfactant ${ }^{3}$ in $\mathrm{H}_{2} \mathrm{O}$ was applied to $1 \mathrm{~cm}^{2}$ of the leaf. Approximately $0.023 \mu \mathrm{Ci}$ of uniformly ring-labeled ${ }^{14} \mathrm{C}$-picloram (specific activity $16.85 \mathrm{mCi} / \mathrm{mmole}$ ) was then applied in $5 \mu \mathrm{l}$ of 80 degrees o $(\mathrm{v} / \mathrm{v})$ ethanol followed by an additional $5 \mu \mathrm{l}$ of the surfactant solution. Unlabeled picloram was added to the surfactant solution to achieve a total picloram rate of $0.28 \mathrm{~kg} / \mathrm{ha}$. Plants were returned to the growth chambers immediately after treatment. Plants were transferred between growth chambers to achieve the following posttreatment humidity regimes: a) 72 hours at low humidity, b) 1 hour at high followed by 71 hours at low humidity, c) 6 hours at high followed by 66 hours at low humidity, d) 24 hours at high followed by 48 hours at low humidity, e) 48 hours at high followed by 24 hours at low humidity and f) 24 hours at low followed by 48 hours at high humidity.

Plants were harvested 72 hours after treatment and sectioned into the treated leaf, shoot, and roots. The roots were washed with water to remove soil, and the treated leaf was quickly dipped 10 times into $15 \mathrm{ml}$ of scintillation fluid 'A' $\{1: 1 . \mathrm{v} / \mathrm{v}$, toluene:ethanol plus $5 \mathrm{~g} / \mathrm{L}$ PPO (2,5-diphenyloxazole) and $0.5-\mathrm{g} / \mathrm{L}$ dimethyl-POPOP [1,4-bis2-(4-methyl-5-phenyloxazolyl)benzene]\} to remove unabsorbed ${ }^{14} \mathrm{C}$-picloram. Plant sections were dried at $60^{\circ} \mathrm{C}$ for 24 hours and root and shoot sections were ground in a Wiley mill (=10-mesh screen) and weighed. The treated leaf and two or more 120- to 150 -mg

\footnotetext{
${ }^{3}$ Surfactant WK (dodecyl ether of polyethylene glycol), E. I. DuPont de Nemours and Co., Wilmington, DE.
} 
root or shoot sub-samples equaling at least $10 \%$ of the sample weight were each combusted in a biological materials oxidizer (BMO) ${ }^{4}$. The ${ }^{14} \mathrm{CO}_{2}$ was collected in $15 \mathrm{ml}$ of scintillation fluid ' $\mathrm{B}$ ' $(10: 7: 3, \mathrm{v} / \mathrm{v} / \mathrm{v}$, toluene: 2-methoxyethanol:ethanolamine plus 5.0 $\mathrm{g} / \mathrm{L}$ PPO and $0.5 \mathrm{~g} / \mathrm{L}$ dimethyl-POPOP). Samples were assayed using liquid scintillation spectrometry. BMO efficiency was determined using ${ }^{14} \mathrm{C}$-methyl methacrylate and liquid scintillation counting efficiency was determined using an external standards ratio.

The effect of temperature on ${ }^{14} \mathrm{C}$-picloram absorption and translocation was evaluated using similar experimental procedures as the humidity experiment, except plants were transferred from the greenhouse to growth chambers 48 hours before treatment. Growth chamber conditions were either high $\left(30 / 18^{\circ} \mathrm{C}\right.$ day/night $)$ or low $\left(18 / 10^{\circ} \mathrm{C}\right.$ day/night $)$ temperatures at 20 to $30 \%$ relative humidity.

Plants were treated as previously described and transferred between growth chambers to achieve the following posttreatment temperature regimes: a) 72 hours at high temperature, b) 48 hours at high followed by 24 hours at low temperature, c) 24 hours at high followed by 48 hours at low temperature, d) 72 hours at low temperature, e) 48 hours at low followed by 24 hours at high temperature, and f) 24 hours at low followed by 48 hours at high temperature.

\section{Ammonium salts}

Picloram at $0.28 \mathrm{~kg} / \mathrm{ha}$ was spray applied with $0.25 \%(\mathrm{v} / \mathrm{v})$ nonionic surfactant to leafy spurge plants (except one enclosed leaf) alone and in combination with ammonium sulfate or ammonium nitrate, each at 0.5 and $2.5 \mathrm{~kg} / \mathrm{ha} .{ }^{14} \mathrm{C}$-picloram was applied to the untreated leaf as previously described followed by $5 \mu \mathrm{l}$ of $0.25 \%(\mathrm{v} / \mathrm{v})$ surfactant $^{3}$ containing ammonium sulfate or ammonium nitrate and sufficient unlabeled picloram to achieve a total ${ }^{14} \mathrm{C}$-picloram plus picloram rate of $0.28 \mathrm{~kg} / \mathrm{ha}$. Plants were maintained in growth chambers at 20 to $30 \%$ relative humidity with a $30 / 18^{\circ} \mathrm{C}$ day/night temperature and 16-hourslight period 48 hours prior to and 72 hours following treatment.

\section{Buffers}

The effect of spray solution $\mathrm{pH}$ on ${ }^{14} \mathrm{C}$-picloram absorption and translocation was evaluated using buffered and unbuffered spray solutions. Leafy spurge plants were treated with picloram and ${ }^{14} \mathrm{C}$-picloram in unbuffered spray solutions adjusted to $\mathrm{pH} 3,5$, 7, and 9 with $\mathrm{HCl}$ or $\mathrm{KOH}$. Experimental procedures were similar to those used for the ammonium salts experiment except no surfactant was applied.

Plants were treated in a second experiment with picloram and ${ }^{14} \mathrm{C}$-picloram solutions buffered with $50 \mathrm{mM}$ trisodium citrate or $50 \mathrm{mM}$ sodium bicarbonate $\left(\mathrm{NaHCO}_{3}\right)$, and adjusted to approximate buffer $\mathrm{pKa}$ values as listed by Cooper (5). Citrate-buffered solu-

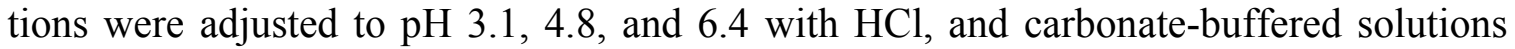
were adjusted to $\mathrm{pH} 6.4$ and 10.3 with $\mathrm{HCl}$ and $\mathrm{KOH}$, respectively.

\footnotetext{
${ }^{4}$ (Model OX400. R. J. Harvey Instrument Corp., Hillsdale, N.J.)
} 
The effect of various buffering agents on absorption of ${ }^{14} \mathrm{C}$-picloram was determined with detached leafy spurge leaves. Leafy spurge shoots at the mid- to late-vegetative growth stage were obtained directly from the same natural infestation previously described to simulate field conditions as closely as possible. Leaves were excised and treated 2 to 6 hours after shoot collection. Cut ends of the stems were placed in water to maintain shoot turgidity during transport from the field. Receptacles to hold leaves during the experiments were constructed from $1.3-\mathrm{cm}$ diameter polyethylene tubing. A $3-\mathrm{cm}$ length of tubing was embedded vertically in paraffin contained in a 2.5 -cm-diam by 0.8 $\mathrm{cm}$ planchet. A slit was cut in the tubing $2 \mathrm{~cm}$ from the base and approximately one-third the distance around the circumference of the tubing through which the basal portion of a single leaf was inserted. The well of the receptacle was filled with distilled water to maintain leaf turgidity.

Picloram at $0.28 \mathrm{~kg} / \mathrm{ha}$ was applied to the leaf in a $5-\mu 1$ droplet of an aqueous solution buffered with trisodium citrate, oxalicacid $\left(\mathrm{H}_{2} \mathrm{C}_{2} \mathrm{O}_{4}\right)$, sodium acetate $\left(\mathrm{Na}_{2} \mathrm{C}_{2} \mathrm{H}_{3} \mathrm{O}_{2} \bullet 3\right.$ $\left.\mathrm{H}_{2} \mathrm{O}\right)$, or potassium-sodium tartrate $\left(\mathrm{KNaC}_{4} \mathrm{H}_{4} \mathrm{O}_{6} \cdot 4 \mathrm{H}_{2} \mathrm{O}\right)$. Approximately $0.01 \mu \mathrm{Ci}{ }^{14} \mathrm{C}$ picloram in $5 \mu 1$ of $80 \%(\mathrm{v} / \mathrm{v})$ ethanol was injected into the droplet using a microsyringe. An unbuffered ${ }^{14} \mathrm{C}$-picloram solution adjusted to $\mathrm{pH} 4.5$ was included as a control. Solutions buffered with an acid or salt were adjusted to $\mathrm{pH} 4.5$ with $\mathrm{KOH}$ or $\mathrm{HCl}$, respectively.

The leaves were placed under fluorescent light $\left(120 \mu \mathrm{E} \cdot \mathrm{m}^{-2} \cdot \mathrm{s}^{-1}\right)$ after treatment and maintained in the lab at ambient temperature and humidity. Leaves were harvested 48 hours after treatment and were dipped 10 times in $15 \mathrm{ml}$ of scintillation fluid ' $\mathrm{A}$ ' to remove unabsorbed ${ }^{14} \mathrm{C}$-picloram. Leaves were combusted in a $\mathrm{BMO}$, and ${ }^{14} \mathrm{C}$ in the leaf and leaf wash was quantified as previously described.

The effect of buffer concentration on ${ }^{14} \mathrm{C}$-picloram absorption was determined. ${ }^{14} \mathrm{C}$-picloram in unbuffered and $10,25,50$, and $100 \mathrm{mM}$ citrate-buffered solutions adjusted to $\mathrm{pH} 4.8$ with HCI was applied to detached leafy spurge leaves as previously described. Also, the effect of $\mathrm{pH}$ on ${ }^{14} \mathrm{C}$-picloram absorption in buffered solutions was evaluated. Detached leafy spurge leaves were treated with unbuffered and citratebuffered ${ }^{14} \mathrm{C}$-picloram solutions adjusted to $\mathrm{pH} 3.1,4.8$, and 6.4 with $\mathrm{HCl}$. Leaves were harvested 48 hours after treatment.

\section{Statistical analyses}

All experiments were conducted twice and had similar variances, so the combined data are presented. Experiments were in a randomized complete block design with five replicates/treatment (growth chamber) and a factorial arrangement of pre- and posttreatment humidity or temperature. The ammonium salts, buffer, and $\mathrm{pH}$ experiments were completely random designs. The whole plant and detached leaf experiments had five and six replications, respectively. The data were subjected to analysis of variance and means were separated using a protected LSD test. 


\section{Results and discussion}

\section{Humidity and temperature}

Picloram generally is not catabolized in plants including leafy spurge but slowly forms conjugates with simple sugars (mostly glucose) 72 hours or more after treatment $(7,20,23)$. Since plants were harvested 48 to 72 hours after treatment in these experiments and metabolites were not detected in preliminary experiments (11), the ${ }^{14} \mathrm{C}$ recovered will be referred to as ${ }^{14} \mathrm{C}$-picloram.

Absorption and translocation of ${ }^{14} \mathrm{C}$-picloram were similar in leafy spurge preconditioned at high or low humidity for 24 hours prior to treatment (data not shown). However, absorption in leafy spurge increased from 11 to $34 \%$ and translocation to shoot and root increased from 5 to $21 \%$ of the ${ }^{14} \mathrm{C}$-picloram applied as posttreatment time at high humidity increased from 0 to 48 hours (Table 1). Translocation to leafy spurge roots increased from 2 to $4 \%$ of the ${ }^{14} \mathrm{C}$-picloram applied as time at high humidity after treatment increased from 0 to 48 hours. Unpublished research showed almost half of the ${ }^{14} \mathrm{C}$-picloram that translocated to leafy spurge roots was released into the root media (11). Thus, the actual amount of ${ }^{14} \mathrm{C}$-picloram translocated to the roots was probably higher than the amounts reported in these studies. However, only the amount retained is considered effective in controlling leafy spurge root growth (13).

Table 1. Absorption and translocation of ${ }^{14} \mathrm{C}$-picloram in leafy spurge 72 hours after treatment as influenced by posttreatment humidity averaged over pretreatment humidity.

\begin{tabular}{|c|c|c|c|c|c|c|}
\hline \multicolumn{3}{|c|}{ Relative humidity $^{\mathrm{a}}$} & \multicolumn{3}{|c|}{ Plant section } & \multirow[b]{2}{*}{ Total } \\
\hline High & Low & High & Treated leaf & Shoot & Root & \\
\hline \multicolumn{3}{|c|}{$-(h)$} & \multicolumn{4}{|c|}{ - $(\%$ of applied $)$} \\
\hline 0 & 72 & ... & 6 & 3 & 2 & 11 \\
\hline 1 & 71 & $\ldots$ & 5 & 3 & 2 & 10 \\
\hline 6 & 66 & $\ldots$ & 7 & 7 & 3 & 17 \\
\hline 24 & 48 & $\ldots$ & 12 & 9 & 3 & 24 \\
\hline 48 & 24 & $\ldots$ & 13 & 17 & 4 & 34 \\
\hline$\ldots$ & 24 & 48 & 13 & 6 & 2 & 21 \\
\hline $\operatorname{LSD}(0.05)$ & & & 3 & 4 & 1 & 5 \\
\hline
\end{tabular}

${ }^{\text {a }}$ Plants were preconditioned at $30 / 18^{\circ} \mathrm{C}$ day/night temperatures and high (90 to $95 \%$ ) or low (20 to $30 \%$ ) relative humidity for 24 hours before treatment.

${ }^{14} \mathrm{C}$-picloram accumulated in the shoot more than the root of leafy spurge as time at high humidity increased (Table 1). A 48-hour period of high humidity after treatment followed by 24 hours at low humidity increased ${ }^{14} \mathrm{C}$-picloram translocation to the shoot in leafy spurge more than 24 hours at low humidity after treatment followed by 48 hours at high humidity did. Translocation of ${ }^{14} \mathrm{C}$-picloram following posttreatment high humidity was nearly six times greater to the shoot but only two times greater to the root after 48 hours compared to low humidity following treatment. Picloram is both phloem and xylem 
mobile $(20,23)$. Picloram also moves from phloem to xylem $(9,21)$. Acropetal translocation of ${ }^{14} \mathrm{C}$-picloram in the transpiration stream of leafy spurge, therefore, should be less at high than at low humidity. Basipetal translocation of foliar-applied or stem-injected herbicides was greater at high than low humidity $(1,21)$. Perhaps increasing periods at high humidity following treatment promoted absorption and translocation of ${ }^{14} \mathrm{C}$ picloram by influencing such factors as leaf cuticle hydration and leaf cell and phloem conduit turgidity.

Absorption and translocation of ${ }^{14} \mathrm{C}$-picloram were similar in leafy spurge preconditioned at high or low temperature for 48 hours prior to treatment (data not shown). Absorption and translocation of ${ }^{14} \mathrm{C}$-picloram in leafy spurge were not influenced by temperature after treatment (Table 2). These results differ from those of Sharma and Vanden Born (22) who reported that absorption of picloram by aspen poplar was greater at high than at low temperature.

Table 2. Absorption and translocation of ${ }^{14} \mathrm{C}$-picloram in leafy spurge 72 hours after treatment as influenced by posttreatment temperature averaged over pretreatment temperature.

\begin{tabular}{|c|c|c|c|c|c|c|}
\hline \multicolumn{3}{|c|}{ Temp. (C) (day/night) $)^{\mathrm{a}}$} & \multicolumn{3}{|c|}{ Plant section } & \multirow[b]{2}{*}{ Total } \\
\hline $30 / 18$ & $18 / 10$ & $30 / 18$ & Treated leaf & Shoot & Root & \\
\hline \multicolumn{3}{|c|}{$-(\mathrm{h})$} & \multicolumn{3}{|c|}{ - (\%of applied $)-$} & \\
\hline 24 & 48 & $\ldots$ & 4 & 2 & 2 & 8 \\
\hline$\ldots$ & 72 & 0 & 3 & 2 & 2 & 7 \\
\hline$\ldots$ & 48 & 24 & 4 & 2 & 2 & 8 \\
\hline$\ldots$ & 24 & 48 & 5 & 2 & 2 & 9 \\
\hline $\operatorname{LSD}(0.0$ & & & NS & NS & NS & NS \\
\hline
\end{tabular}

${ }^{a}$ Plants were preconditioned at 20 to $30 \%$ relative humidity and $30 / 18$ or $18 / 10^{\circ} \mathrm{C}$ day/night temperatures for 48 hours before treatment.

Maximum absorption and translocation of ${ }^{14} \mathrm{C}$-picloram in leafy spurge was only 9 and $4 \%$ of the applied ${ }^{14} \mathrm{C}$-picloram, respectively, for the temperature experiment (Table 2 ). Relatively low levels of absorption were probably the result of low relative humidity (20 to $30 \%$ ) after treatment. Thus, posttreatment humidity seems to influence picloram absorption and translocation in leafy spurge more than posttreatment temperature does.

\section{Ammonium salts}

Absorption and translocation of ${ }^{14} \mathrm{C}$-picloram in leafy spurge increased at least $200 \%$ when ${ }^{14} \mathrm{C}$-picloram was applied with 0.5 and $2.5 \mathrm{~kg} / \mathrm{ha}$ ammonium sulfate than when applied alone (Table 3). Translocation to the roots of leafy spurge averaged $11 \%$ of applied ${ }^{14} \mathrm{C}$ when applied with ammonium sulfate, compared to $6 \%$ when ${ }^{14} \mathrm{C}$-picloram was applied alone. Unlike ammonium sulfate, ammonium nitrate did not affect absorption and translocation of ${ }^{14} \mathrm{C}$-picloram in leafy spurge. 
These results differ from those of Wilson and Nishimoto (35) who reported that ammonium nitrate was similar to ammonium sulfate in enhancing ${ }^{14} \mathrm{C}$-picloram absorption by strawberry guava leaves. However, ammonium sulfate but not ammonium nitrate enhanced weed control with glyphosate [ $N$-(phosphonomethyl) glycine] $(3,26)$. The influence on phytotoxicity of an ammonium salt applied with an herbicide may be dependent on plant species. Ammonium sulfate applied with glyphosate increased control of some but not all weed species (26).

Table 3. Absorption and translocation of ${ }^{14} \mathrm{C}$-picloram applied with ammonium sulfate or ammonium nitrate in leafy spurge 72 hours after treatment ${ }^{\mathrm{a}}$.

\begin{tabular}{lccccc}
\hline & & \multicolumn{3}{c}{ Plant section } & \multirow{2}{*}{ Total } \\
\cline { 3 - 4 } Ammonium salt & Rate & Treated leaf & Shoot & Root & \\
\cline { 3 - 5 } None & $(\mathrm{kg} / \mathrm{ha})$ & 6 & 6 & \% of applied $)$ & 18 \\
Sulfate & 0 & 11 & 15 & 10 & 36 \\
& 0.5 & 14 & 20 & 12 & 46 \\
Nitrate & 2.5 & 6 & 8 & 6 & 20 \\
& 0.5 & 5 & 3 & 4 & 12 \\
LSD $(0.05)$ & 2.5 & 4 & 5 & 3 & 6
\end{tabular}

${ }^{\mathrm{a}}$ Plants were maintained at 20 to $30 \%$ relative humidity and $30 / 18^{\circ} \mathrm{C}$ day/night temperature for 48 hours before and 72 hours following treatment.

Turner and Loader $(30,31)$ suggested that ammonium salts increase the rate of herbicide penetration through leaf surfaces. Ammonium sulfate may have increased ${ }^{14} \mathrm{C}$ picloram absorption in leafy spurge by affecting plant rather than spray droplet characteristics. The activity of 2,4-D on bean and sunflower (Helianthus annuus L.) was greater when 2,4-D was applied with ammonium nitrate than when applied alone (28). Ammonium nitrate, however, did not alter surface tension, contact angle, or spreading coefficient of the 2,4-D plus ammonium nitrate solution compared to 2,4-D alone. Poovaiah and Leopold (15) suggested that $\mathrm{NH}_{4}+$ and $\mathrm{SO}_{4}{ }^{--}$ions may "salt out" macromolecules in plant cell membranes, thereby influencing membrane permeability to aqueous solutions. Ammonium sulfate may have increased the permeability of leafy spurge leaf cells to ${ }^{14}$ C-picloram.

\section{Buffers}

Absorption and translocation of ${ }^{14} \mathrm{C}$-picloram in leafy spurge whole plants were similar regardless of unbuffered solution $\mathrm{pH}$ (Table 4). ${ }^{14} \mathrm{C}$-picloram absorption and translocation to the root averaged 22 and $5.5 \%$, respectively, at $\mathrm{pH} 3$ to 9 . These results agree with those of Wilson and Nishimoto (35) who reported that ${ }^{14} \mathrm{C}$-picloram absorption in strawberry guava leaves was independent of unbuffered solution $\mathrm{pH}$. Picloram absorption, however, was greater in live oak leaves treated with unbuffered picloram solutions at $\mathrm{pH} 4$ and 6 compared to $\mathrm{pH} 7$ and 8 (2). 
The buffering capacity of the treated leafy spurge leaf may have been sufficient to overcome the influence of $\mathrm{pH}$ in unbuffered ${ }^{14} \mathrm{C}$-picloram solutions. The effect of $\mathrm{pH}$ on the activity of a compound entering plant tissue may be masked if the buffering capacity of the plant exceeds that of the spray solution (25). A herbicide, therefore, may reach most plant cells at a $\mathrm{pH}$ related to that of the plant, independent of the spray solution $\mathrm{pH}$ (24).

Absorption of ${ }^{14} \mathrm{C}$-picloram in leafy spurge was greater when ${ }^{14} \mathrm{C}$-picloram was applied in a buffered solution at $\mathrm{pH} 3.1$ and 4.8 than at $\mathrm{pH} 6.4$ and 10.3 (Table 4). ${ }^{14} \mathrm{C}$ picloram absorption averaged $33 \%$ at $\mathrm{pH} 3.1$ and 4.8 compared to $10 \%$ at $\mathrm{pH} 6.4$ and 10.3. These data generally agree with literature reporting that absorption of weak acids such as picloram, 2,4-D, and 2,4,5-T in plants is greater at low than at high herbicide solution $\mathrm{pH}(2,17,19)$.

Table 4. Absorption and translocation of ${ }^{14} \mathrm{C}$-picloram applied in $\mathrm{pH}$-adjusted solutions with or without a $\mathrm{pH}$ buffer in leafy spurge 72 hours after treatment ${ }^{\mathrm{a}}$.

\begin{tabular}{|c|c|c|c|c|}
\hline \multirow[b]{2}{*}{ Solution $\mathrm{pH}$} & \multicolumn{3}{|c|}{ Plant section } & \multirow[b]{2}{*}{ Tota } \\
\hline & Treated leaf & Shoot & Root & \\
\hline \multicolumn{5}{|l|}{ Unbuffered: } \\
\hline 3 & 10 & 7 & 5 & 22 \\
\hline 5 & 7 & 7 & 4 & 18 \\
\hline 7 & 10 & 10 & 6 & 26 \\
\hline 9 & 9 & 7 & 6 & 22 \\
\hline $\operatorname{LSD}(0.05)$ & NS & NS & NS & NS \\
\hline \multicolumn{5}{|l|}{ Buffered: } \\
\hline $3.1+$ citrate $^{\mathrm{b}}$ & 16 & 4 & 3 & 23 \\
\hline $4.8+$ citrate $^{\mathrm{b}}$ & 18 & 17 & 8 & 43 \\
\hline $6.4+$ citrate $^{\mathrm{b}}$ & 6 & 3 & 3 & 12 \\
\hline $6.4+$ carbonate $^{\mathrm{c}}$ & 4 & 1 & 1 & 6 \\
\hline $10.3+$ carbonate $^{\mathrm{c}}$ & 7 & 2 & 3 & 11 \\
\hline $\operatorname{LSD}(0.05)$ & 4 & 3 & 2 & 5 \\
\hline
\end{tabular}

Translocation of ${ }^{14} \mathrm{C}$-picloram to leafy spurge shoot and root was greater when ${ }^{14} \mathrm{C}$ picloram was applied at $\mathrm{pH} 4.8$ than when applied at $\mathrm{pH} 3.1,6.4$, and 10.3 (Table 4). Translocation to the root and shoot of leafy spurge was increased at least two and a half and four times at $\mathrm{pH} 4.8$, respectively, compared to $\mathrm{pH} 3.1,6.4$, and 10.3 . The $\mathrm{H}^{+}$ion concentration at $\mathrm{pH} 3.1$ may have damaged leafy spurge leaf tissue and limited the absorption and translocation of ${ }^{14} \mathrm{C}$-picloram compared to $\mathrm{pH} 4.8$, although no injury to the treated leaf was visible. Leafy spurge translocated 58 and $30 \%$ of the absorbed ${ }^{14} \mathrm{C}$ picloram at $\mathrm{pH} 4.8$ and 3.1, respectively. Accumulation of ${ }^{14} \mathrm{C}$-picloram in the injured leaf rather than translocation out of the leaf also may have limited absorption at $\mathrm{pH} 3.1$. 
Absorption and translocation of ${ }^{14} \mathrm{C}$-picloram in leafy spurge tended to be greater with a citrate-buffered than with a carbonate-buffered ${ }^{14} \mathrm{C}$-picloram solution at $\mathrm{pH} 6.4$ (Table 4). Compounds included in the spray mixture may interact differently with surfactant, picloram, or leafy spurge leaf tissue and, therefore, influence ${ }^{14} \mathrm{C}$-picloram absorption and translocation. Quackgrass [Agropyron repens (L.) Beauv.] control with glyphosate was influenced by the organic acid included in the spray mixture (29).

Picloram is less dissociated at low than high $\mathrm{pH}$ (27). Undissociated ${ }^{14} \mathrm{C}$-picloram may have been absorbed by the lipophilic leaf tissue of leafy spurge more readily than dissociated ${ }^{14} \mathrm{C}$-picloram anions. Baur et al. (2) suggested that a low rather than a high spray solution $\mathrm{pH}$ favors penetration of undissociated picloram molecules through a leaf cuticle. Sargent (18) stated that the undissociated 2,4-D molecule was more soluble than the 2,4-D anion in the lipoidal phases of plant epidermal layers, which in part accounted for increased 2,4-D absorption at low rather than high $\mathrm{pH}$.

A low spray solution $\mathrm{pH}$ may have increased ${ }^{14} \mathrm{C}$-picloram absorption by inducing changes in the treated leaf of leafy spurge. The $\mathrm{pH}$ of a solution applied to a plant may affect the dissociation of free acid groups in both the cuticle and plasmalemma, and changes in charge at these surfaces may alter the rate at which ions penetrate (32). $\mathrm{H}^{+}$ ions also affect cell walls $(16,33)$. Rayle and Cleland (16) suggested that $\mathrm{H}^{+}$ions may cleave acid-labile bonds or activate an enzymatic process in plant cell walls resulting in loosening of the cell wall structure. $\mathrm{H}^{+}$-induced changes in the epidermal cell walls of the treated leafy spurge leaf may have increased the permeability of cells to ${ }^{14} \mathrm{C}$-picloram.

Oxalate- and citrate- but not acetate- and tartrate-buffered solutions increased the absorption of ${ }^{14} \mathrm{C}$-picloram in detached leafy spurge leaves compared to an unbuffered treatment solution (Table 5). ${ }^{14} \mathrm{C}$-picloram absorption increased from 25 to $44 \%$ when the treatment solution was buffered with trisodium citrate compared to an unbuffered solution. The reason(s) the various buffers produced different absorption of ${ }^{14} \mathrm{C}$-picloram are not known. The buffered solutions were adjusted to $\mathrm{pH} 4.5$, which is less than $0.25 \mathrm{pH}$ units from the $\mathrm{pKa}_{2}$ of each buffer. The buffered solutions, therefore, should have had similar buffering capacity. The buffers may have interacted differently with the surfactant in the treatment solution or had differing effects on the cuticle or underlying membranes of the leaf epidermis which, caused differences in ${ }^{14} \mathrm{C}$-picloram absorption.

Effects of buffer concentration and the $\mathrm{pH}$ of the buffered solution on absorption of ${ }^{14} \mathrm{C}$-picloram were evaluated using trisodium citrate since it had increased picloram absorption more than other buffering agents surveyed. Absorption of ${ }^{14} \mathrm{C}$-picloram in detached leafy spurge leaves increased as citrate-buffer concentration increased from 10 to $100 \mathrm{mM}$ (Table 5). Increasing the buffer concentration in the ${ }^{14} \mathrm{C}$-picloram solutions apparently decreased the ability of the treated leaf to buffer $\mathrm{pH}$-adjusted solutions toward the physiological $\mathrm{pH}$ of the leaf tissue.

Absorption of ${ }^{14} \mathrm{C}$-picloram in detached leafy spurge leaves was similar regardless of unbuffered solution $\mathrm{pH}$ (Table 5). These data are similar to those obtained from intact plants treated with unbuffered, $\mathrm{pH}$-adjusted ${ }^{14} \mathrm{C}$-picloram solutions (Table 4). Adjusting the $\mathrm{pH}$ of buffered ${ }^{14} \mathrm{C}$-picloram solutions had minimal effect on ${ }^{14} \mathrm{C}$-picloram absorption in leafy spurge. Trisodium citrate at $\mathrm{pH} 4.8$ but not 3.1 or 6.4 increased ${ }^{14} \mathrm{C}$-picloram absorption in the treated leaf compared to unbuffered treatments at a similar $\mathrm{pH}$ (Table 5). 
Detached leafy spurge leaves absorbed nearly twice as much ${ }^{14} \mathrm{C}$-picloram applied in citrate-buffered solutions at $\mathrm{pH} 4.8$ than at 6.4.

Application of picloram during periods of high humidity and tank mixed with ammonium sulfate or at $\mathrm{pH} 4.8$ buffered with trisodium citrate should provide increased picloram translocation to leafy spurge roots. Leafy spurge control with picloram alone and tank mixed with these additives are being evaluated in the field.

Table 5. Absorption of ${ }^{14} \mathrm{C}$-picloram by detached leafy spurge leaves in pH-buffered solutions as influenced by: a) type of buffer, b) buffer concentration, and c) buffered solution $\mathrm{pH}, 48$ hours after treatment at ambient temperature.

\begin{tabular}{|c|c|}
\hline Main effect & ${ }^{14} \mathrm{C}$-picloram absorbed \\
\hline & (\% of applied) \\
\hline \multicolumn{2}{|l|}{ Buffer $(50 \mathrm{mM})^{\mathrm{a}:}$ : } \\
\hline None & 25 \\
\hline Oxalic acid & 35 \\
\hline Sodium acetate & 20 \\
\hline Trisodium citrate & 44 \\
\hline Potassium -sodium tartrate & 20 \\
\hline $\operatorname{LSD}(0.05)$ & 7 \\
\hline \multicolumn{2}{|l|}{$\begin{array}{l}\text { Trisodium citrate conc. }{ }^{\mathrm{b}} \text { : } \\
\qquad(\mathrm{mM})\end{array}$} \\
\hline Unbuffered & 20 \\
\hline 10 & 26 \\
\hline 25 & 32 \\
\hline 50 & 38 \\
\hline 100 & 51 \\
\hline $\operatorname{LSD}(0.05)$ & 7 \\
\hline \multicolumn{2}{|l|}{ Solution $\mathrm{pH}$ : } \\
\hline 3.1 unbuffered & 25 \\
\hline 4.8 unbuffered & 24 \\
\hline 6.4 unbuffered & 22 \\
\hline $3.1+50 \mathrm{mM}$ trisodium citrate & 30 \\
\hline $4.8+50 \mathrm{mM}$ trisodium citrate & 42 \\
\hline $6.4+50 \mathrm{mM}$ trisodium citrate & 22 \\
\hline $\operatorname{LSD}(0.05)$ & 6 \\
\hline
\end{tabular}

${ }^{\mathrm{a}}$ Solutions buffered with an acid or salt were adjusted to $\mathrm{pH} 4.5$ with $\mathrm{KOH}$ or $\mathrm{HCI}$, respectively.

${ }^{\mathrm{b}}$ All solutions adjusted to $\mathrm{pH} 4.8$ with $\mathrm{HCI}$. 


\section{Literature cited}

1. Basler, E., F.W. Slife, and J.W. Long. 1970. Some effects of humidity on the translocation of 2,4,5-T in bean plants. Weed Sci. 18:396-398.

2. Baur, J.R., R.W. Bovey, and I. Riley. 1971. Absorption and penetration of picloram and 2,4,5-T into detached live oak leaves. Weed Sci. 19:138-141.

3. Blair, A.M. 1975. The addition of ammonium salt or a phosphate ester to herbicides to control Agropyron repens (L.) Beauv. Weed Res. 15:101-105.

4. Brady, H. A. 1970. Ammonium nitrate and phosphoric acid increase 2,4,5-T absorption by tree leaves. Weed Sci. 18:204-206.

5. Cooper, T. G. 1977. The Tools of Biochemistry. John Wiley and Sons, New York. 423 pp.

6. Eberlein, C. V., R. G. Lym, and C. G. Messersmith. 1982. Leafy spurge identification and control. N.D. Agric. Exp. Stn. Circ. W-765. 4 pp.

7. Frear, D. S., H. R. Swanson, and E. R. Mansager. 1984. Picloram metabolism in leafy spurge: Isolation and identification of $\mathrm{N}$-glucoside, glucose ester, and gentiobiose ester conjugates. Abstract, \#12 Div. Pest. Chem., Nat., Meeting Am. Chem. Soc.

8. Galitz, D.S. and D.G. Davis. 1983. Leafy spurge physiology and anatomy. N.D. Farm Res. 40(5):20-26.

9. Gaudiel, R. and W.H. Vanden Born. 1979. Picloram translocation and redistribution in soybean plants following root uptake. Pestic. Biochem. Physiol. 11: 129-134.

10. Gylling, S. R. and W. E. Arnold. 1985. Efficacy and economics of leafy spurge (Euphorbia esula) control in pastures. Weed Sci. 33:381-385.

11. Hickman, M. V. 1988. Release of picloram from leafy spurge (Euphorbia esula L.) roots. Ph.D. Thesis. North Dakota State Univ. 90 P. Univ. Microfilms, Ann Arbor, Mich. (Diss. Abstr. AAD 88-08316).

12. Isensee, A.R., G.E. Jones, and B.C. Turner. 1971. Root absorption and translocation of picloram by oats and soybeans. Weed Sci. 19:727-731.

13. Lym, R.G. and C.G. Messersmith. 1985. Leafy spurge control and improved forage production with herbicides. J. Range Manage. 38:386-391.

14. Morton, H. L. 1966. Influence of temperature and humidity on foliar absorption, translocation, and metabolism of 2,4,5-T by mesquite seedlings. Weeds 14:136-141.

15. Poovaiah, B. W. and A. C. Leopold. 1974. Hormone-solute interactions in the lettuce hypocotyl hook. Plant Physiol. 54:289-293.

16. Rayle, D.L. and R. Cleland. 1970. Enhancement of wall loosening and elongation by acid solutions. Plant Physiol. 46:250-253.

17. Rolston, M. P. and A. G. Robertson. 1976. Some aspects of the absorption of picloram by gorse (Ulex europaeus L.). Weed Res. 16:81-86.

18. Sargent, J. A. 1965. The penetration of growth regulators into leaves. Annu. Rev. Plant Physiol. $16: 1-12$.

19. Sargent, J. A. and G. E. Blackman. 1962. Studies on foliar penetration. I. Factors controlling the entry of 2,4-dichlorophenoxy acetic acid. J. Exp. Bot. 13:348-368.

20. Scott, P.C. and R.O. Morris. 1970. Quantitative distribution and metabolism of auxin herbicides in roots. Plant Physiol. 46: 680-684.

21. Sharma, M.P., F.Y. Chang, and W.H. Vanden Born. 1971. Penetration and translocation of picloram in Canada thistle. Weed Sci. 19:349-355. 
22. Sharma, M.P. and W.H. Vanden Born. 1970. Foliar penetration of picloram and 2,4-D in aspen and balsam poplar. Weed Sci. 18:57-63.

23. Sharma, M. P. and W. H. Vanden Born. 1973. Uptake, cellular distribution, and metabolism of ${ }^{14} \mathrm{C}$-picloram by excised plant tissues. Physiol. Plant. 29:10-16.

24. Simon, E. W. and H. Beevers. 1952. The effect of $\mathrm{pH}$ on the biological activities of weak acids and bases. II. Other relationships between $\mathrm{pH}$ and activity. New Phytol. 51:191-197.

25. Simon, E. W., H. A. Roberts, and G. E. Blackman. 1952. Studies on the principle of phytotoxicity. III. The $\mathrm{pH}$ factor and the toxicity of 3,5-dinitro-o-cresol, a weak acid. J. Exp. Bot. 3:99-109.

26. Suwunnamek, U. and C. Parker. 1975. Control of Cyperus rotundus with glyphosate: the influence of ammonium sulphate and other additives. Weed Res. 15:13-19.

27. Swanson, C. R. and J. R. Baur. 1969. Absorption and penetration of picloram in potato tuber disks. Weed Sci. 17:311-314.

28. Szabo, S. S. and K. P. Buchholtz. 1961. Penetration of living and non-living surfaces by 2,4-D as influenced by additives. Weeds 9:177-184.

29. Turner, D. J. and M.P.L. Loader. 1978. Complexing agents as herbicide additives. Weed Res. 18:199-207.

30. Turner, D.J. and M.P.L. Loader. 1980. Effect of ammonium sulphate and other additives upon the phytotoxicity of glyphosate to Agropyron repens (L.) Beauv. Weed Res. 20:139-146.

31. Turner, D.J. and M.P.L. Loader. 1984. Effect of ammonium sulphate and related salts on the phytotoxicity of dichlorprop and other herbicides used for broadleafed weed control in cereals. Weed Res. 24:64-77.

32. Van Overbeek, J. 1956. Absorption and translocation of plant regulators. Annu. Rev. Plant Physiol. 7:355-372.

33. Vesper, M.J. 1985. Use of $\mathrm{pH}$ response curve for growth to predict apparent wall $\mathrm{pH}$ in elongating segments of maize coleoptiles and sunflower hypocotyls. Plata 166:96-104.

34. Wilson, B.J. and R.K. Nishimoto. 1975. Ammoniun sulfate enhancement of picloram activity and absorption. Weed Sci. 23:289-296.

35. Wilson, B.J. and R.K. Nishimoto. 1975. Ammonium sulfate enhancement of picloram absorption by detached leaves. Weed Sci. 23:297-301. 